\title{
ANALYSIS OF SETTLEMENT AVAILABILITY AT MANYAR ECONOMIC DISTRICT STRATEGIC AREA OF GRESIK REGENCY
}

\author{
ANALISIS KETERSEDIAAN PERMUKIMAN \\ DI KAWASAN STRATEGIS EKONOMI MANYAR DI KABUPATEN GRESIK
}

\author{
${ }^{* 1}$ Anak Agung Sagung Alit Widyastuty, Annisa B Tribhuwaneswari", \\ dan Lutfi Zulkarnain ${ }^{3}$ \\ Faculty of Engineering \\ Universitas PGRI Adi Buana Surabaya
}

Submitted: 20-01-2021; Revised: 08-04-2021; Accepted:30-04-2021

\begin{abstract}
Rapid development and increasing population density have created challenge for many regions to provide settlement spaces. The demand for settlement requires analysis that can forecast on the availability of space and the growth of settlement. Such a challenge is faced by Manyar sub-district of Gresik regency. Since it became an Economic Strategic District Area in the agroindustry area in Gresik Regency, the demand for settlement at Manyar increased following the 2017 population boom. Manyar is recorded as the third maximum growth in Gresik regency with numbers of 114.056 inhabitant living in 9.542 acre. This study aims to examine the facilities and infrastructure, as well as the availability of residential land in the next 20 years. This study uses quantitative technique that includes projections of settlement demand. Data collection methods takes the form of field observations and surveys of related agencies. The analytical technique utilized was backlog and scalogram study regarding the availability of settlement, facilities and infrastructure support. As the result, this paper found that the population growth rate of Manyar sub-district reaches $0.1 \%$ every year. Consequently, the settlement and supporting infrastructures required at the year 2039 increase massively since 2019 consists of housing facilities, education, health facilities, worship facilities, commerce and services facilities, and green open spaces. The land required for the development of the facility is 269.1 acre. Based on the level of need for residential facilities and infrastructure in the next 20 years in Manyar sub-district, further research is needed to anticipate the phenomenon of pond land conversion by maintaining land functions.
\end{abstract}

Keywords: Availability; Population growth; Settlement and infrastructure planning.

\begin{abstract}
ABSTRAK
Perkembangan dan pertumbuhan penduduk telah menghadapi berbagai tantangan di setiap daerah dalam hal menyiapkan tempat permukiman. Kebutuhan akan permukiman penduduk membutuhkan analisis yang dapat memprediksikan kebutuhan tempat dan ruang untuk perkembangan permukiman penduduk. Misalnya, tantangan yang dihadapi di Kecamatan Manyar. Sejak menjadi kawasan strategis ekonomi dalam sektor agro industri di Kabupaten Gresik. Kebutuhan akan permukiman meningkat
\end{abstract}

${ }^{*}$ Corresponding author: sagungalit@unipasby.ac.id.

Copyright@ 2021 THE AUTHOR (S). This article is distributed under a Creative Commons Attribution-Share Alike 4.0 International license. Jurnal Kawistara is published by the Graduate School of Universitas Gadjah Mada. 
sejak tahun 2017. Manyar tercatat tiga kali lonjakan penduduk ketiga tertinggi di Kabupaten Gresik. dengan jumlah 114.056 jiwa menghuni di lahan seluas $9.542 \mathrm{Ha}$. Penelitian ini bertujuan untuk mengkaji fasilitas dan infrastruktur, serta ketersedian lahan permukiman dalam 20 tahun ke depan. Metode penelitian yang digunakan adalah teknik quantitatif dengan metode proyeksi kebutuhan permukiman. Teknik pengumpulan data menggunakan observasi lapangan dan survei pada stakeholder terkait. Teknik analisa dengan metode backlog dan scalogram terkait ketersediaan lahan, fasilitas dan infrastruktur penunjang. Kesimpulan dari penelitian ini menunjukkan bahwa rata-rata angka pertumbuhan populasi dari kecamatan Manyar sebesar 0,1 \% per tahun. Dampaknya kebutuhan lahan, fasilitas, dan infrastruktur permukiman pada tahun 2039 akan diperlukan dan meningkat tajam sejak tahun 2019. Kebutuhan tersebut berupa fasilitas permukiman, fasilitas kesehatan, fasilitas edukasi, fasilitas ibadah, fasilitas perbelanjaan serta servis, dan fasilitas ruang terbuka hijau. Lahan yang dibutuhkan untuk pengembangan fasilitas tersebut seluas 269,1 Ha. Berdasarkan besarnya tingkat kebutuhan fasilitas dan infrastruktur permukiman 20 tahun mendatang di kecamatan Manyar, maka perlu adanya penelitian lebih lanjut untuk mengantisipasi terjadinya fenomena konversi lahan tambak dengan mempertahankan fungsi lahan.

\section{Kata Kunci:Ketersediaan;Pertumbuhanpenduduk; Perencanaan permukiman dan infrastruktur.}

\section{INTRODUCTION}

The rapid development and population density growth causes space for settlements to become narrow (Rachmawati \& Widyastuty, 2015). Settlements and their supporting facilities are basic human needs to provide living and socializing with their environment. These basic needs continue to increase naturally as the complexity of community develops, such as the need for social activities, economic activities, and public service activities (Rotinsulu, Franklin, \& Sembel, 2017). This phenomenon also demands the construction of facilities and infrastructure in an area in order to maintain the survival of the community.
Based on Settlement and Housing Areas constitution (Undang-undang Republik Indonesia No. 1 Tahun 2011, 2011) Settlements are part of the residential neighborhood, which consists of more than one housing. Settlements have several types including kampong settlements, residential settlements, traditional settlements, special settlements, coastal settlements in which there are supporting facilities and infrastructure which include educational facilities, health, worship, trade and services, and green open space. The needs for settlements itself are increasing along the growth of the population number. Factors which affect this development were population growth and housing backlog (Rosa, 2013).

This happened especially in strategic economic areas, located in specific areas with higher population density triggered by the people whom lives near the location they needs. It allows the community to fulfill their needs, thus it caused strategic areas has higher population density than other areas. This strategic areas itself is a section which it spatial planning is prioritized because it has an important influence on the economic growth of the surrounding sectors (Undang-undang Republik Indonesia No. 26 Tahun 2007 tentang Penataan Ruang, 2007).

The establishment of a National Strategic Area (KSN) which is oriented towards economic activities causes the need for regional integration and interaction to support each other's economic activities (Putra, Giyarsih, \& Kurniawan, 2017). The strategic area is an area that becomes the main priority in the development of territory. This is very influential in various sectors such as economy, social, culture and community (Afriansyah, Wicaksono, \& Djakfar, 2012). Economic growth with the establishment of a national strategic area has resulted in a large number of migrant residents living and of course needing a place to live for their survival (Mirah, Mononimbar, \& Tilaar, 2017). Land use change is influenced by four factors, political factors, economic factors, demographic factors and cultural factors. Based on Maslow's theory, basic human needs are the 
availability of food, clothing and shelter (Boeree, 2006). So, there is a need for a strategy to provide facilities in settlements to support economic growth activities and of course not damage the carrying capacity of the surrounding environment.

Gresik Regency is one of the regency in East Jaca with an area of 1.191,25 Km2 (2,5\% from the total area of East Java Province) with a fairly high population density in 2017 of 1.103 inhabitants/Km2 (Badan Pusat Statistik, 2018). Gresik Regency according to Gresik district according to Strategic Area Distribution Plan is included in the District Strategic Area with economic purpose (Peraturan Pemerintah Republik Indonesia No. 26 Tahun 2008, 2008). This condition supports Gresik Regency as an area which has fast growth from the development and population sectors.

Gresik Regency Manyar Sub-district has an area of $8 \%$ from the total area of Gresik Regency which consist around $9.542 \mathrm{Ha}$ from $119.125 \mathrm{Ha}$, with third highest population density from other sub-district in the regency (BPS, 2018). The population reach a number of $9 \%$ or 114.056 inhabitant from Gresik Regency of 1.313.826 inhabitant, it has population density of 1.193 inhabitant/ km (Badan Pusat Statistik, 2018). The plan for determining strategic area of Gresik Regency as also stated in The Spatial and Region Plan of Gresik Regency, Manyar sub-district was included in strategic regency as agrobusiness industry area (Peraturan Pemerintah Republik Indonesia No. 26 Tahun 2008, 2008).

High population growth and geographic location in an area prone to flooding and sea water abrasion, it is necessary to provide land for settlement service facilities in Manyar sub-district, Gresik District. This availability projects the need for residential land for the next 20 years. So that it is expected to be able to anticipate the consequences of agribusiness activities in Manyar sub - district. In accordance with the four factors that influence changes in land use, the geographical condition of the area also influences the change. Not all land in Manyar sub - district can be used as a location for residential activ- ities. This is a reason distinguishes Manyar sub - district from other areas which are also the locations of the National Strategic Area.

Anticipation was done to manage the problem of population density boom in the strategic area. This is also to prepare for the slum settlements emergence due to the lack of service to the community's needs for settlement facilities. Owing to the high activity needs of the population, it is undeniable that the need for land will also increase. It requires more residential land than other areas, thus it is crucial to find out how the condition of the availability of residential land along with supporting infrastructure facilities and settlements in the strategic economic area of Manyar Sub-District. The purpose of this study was to determine the condition of the availability of settlements in the economic strategic area of Manyar Sub-District.

This study uses quantitative research by depicting datas on the level of types of settlements, population projections and the conditions of facilities and infrastructure to support settlements. Subjects in this research uses quantitative research by describing data on the level of settlement types, population projections and the conditions if supporting facilities and infrastructure for settlements. this research consists of the distribution of types of settlements, population projections, conditions of supporting facilities and infrastructure as well as conditions of lack of supporting facilities and infrastructure which include facilities (housing, education, health, service commerce and green space), while for infrastructure include (electricity network, telecommunication network, drainage network, clean water network and waste network).

The scope of the area in this study is Manyar sub-district with an area of 9,542.9 $\mathrm{Ha}$. The administrative boundaries of Manyar sub-district from the North side was Bungah sub-district, on the Southern side was Madura Strait and Gresik sub-district, from the East side was Kebomas sub-district, lastly, on the West side was Duduksampeyan sub-district. Figure 1. bellow describes about the administrative limits of Manyar sub-district. 


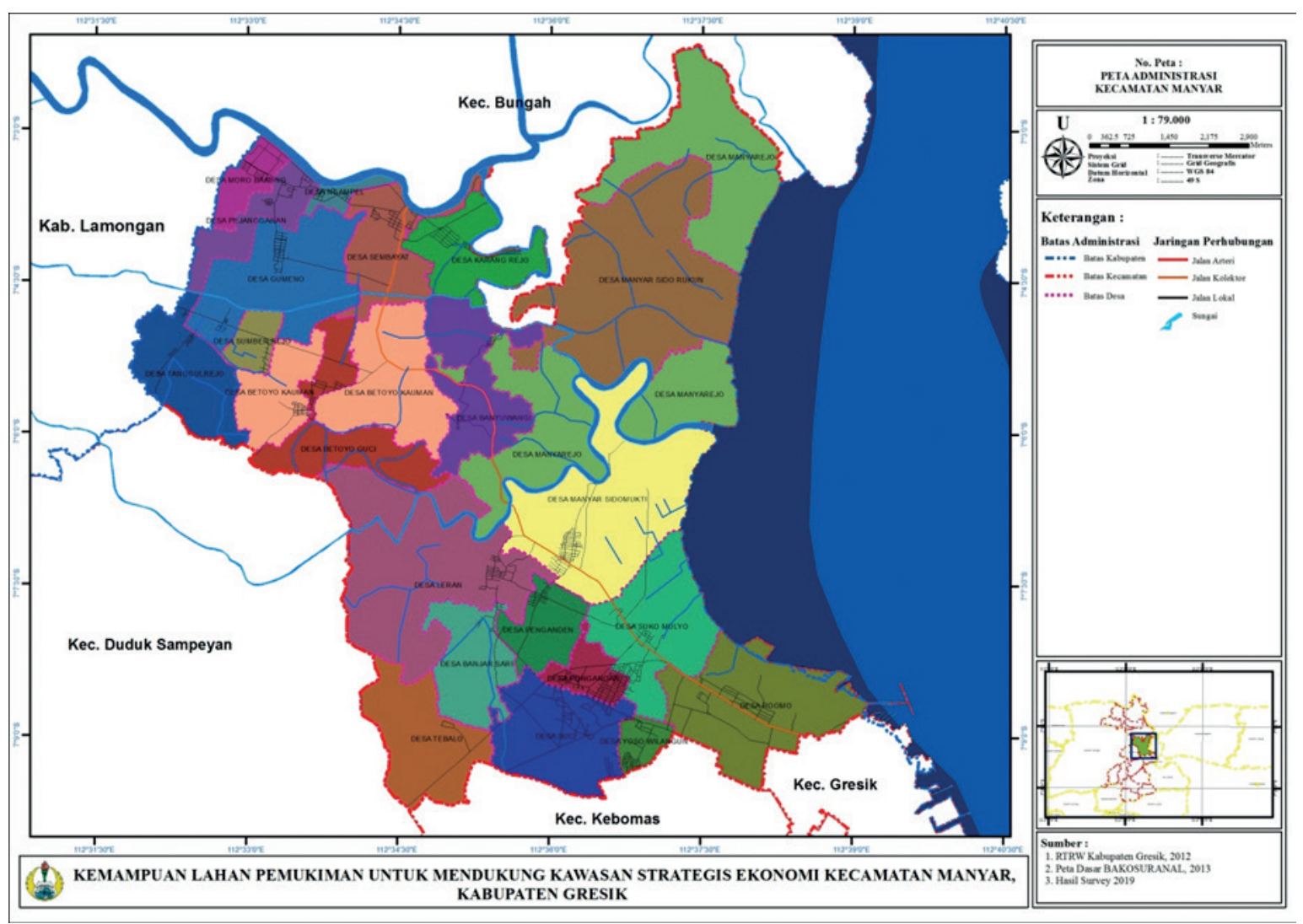

Figure 1.

Administrative Map of Manyar sub-district Resources : Rencana Tata Ruang Kabupaten Gresik 2012(BAPPEDA, 2011), Peta dasar Bakosuranal 2013, survey results 2019.

Data needed in this study consisted of primary data obtained through observation, and documentation and secondary data obtained through BPS data, district datas and literature studies. The analysis technique used in this study is a quantitative descriptive analysis, firststly to know the typology of the avaibility on the settlement area, the polygon area calculation technique were used from the compilation results of the secondary datas and field observation. Secondly, to identify the number and condition of the availability of settlement support facilities and the order of the ranking of the region using the schalogram analysis technique. Thirdly, using the population projection technique to understand the population growth assumption during the next 20 years using exponential methods and the analysis technique for supporting facilities and infrastructure needs based on Indonesian National Standard 2004
(Standar Nasional Indonesia 2004) which is used to determine the level of needs for supporting facilities and infrastructure for settlements. Housing backlog analysis techniques is the number of housing shortages which usually defined as the number of houses that haven't been handled well. It was used to know the needs of housing in the research area (Rosa, 2013).

\section{DISCUSSION}

\section{Distribution and Settlement Types in Manyar Sub-District}

Manyar sub-district is one of the subdistrict located in the Gresik Regenscy. Manyar sub-districy became a strategic area in the regency based on the economic(agrobusiness industry) perspective, thus Manyar subdistrict has some of the settlement typology based on the field survey and analysis of the distribution and types of settlement. 
The results shows it has three types of settlement in the Manyar sub-district which are residential, kampong, and industry. Residential settlement are the settlement which has neat arrangement with well provided facilities and infrastructure, located in the urban area (Undang-undang Republik Indonesia No. 1 Tahun 2011, 2011). Kampong settlement is a settlement located in the urban area with an unplanned development and grown organically(Darmawan \& Utami, 2018). Industry settlement located in the industry area and act as supporting facilities in the industry itself (Anggreini, Wulandari, \& Ramdlani, 2018).

Kampong, residential, and industry settlement in the Manyar sub-district scattered amongs 23 villages in the sub-district. The village which has those three types are Romo Village, Sukomulyo Villafe, and Leran Village. The other 20 village only consist of 1-2 types of setllements, ehich are kampong and residential settlement. Thus for the types of kampong settlements distributed in the Manyar sub-district amidst the 23 villages reach the number of $335.38 \mathrm{Ha}$ or $52 \%$ from the total area of Manyar sub-district settlement. The residential village are $275.28 \mathrm{Ha}$ or $42 \%$ from the entirety of Mantar sub-district. The least area are industry settlement with the amount of $39.84 \mathrm{Ha}$ or $6 \%$ from the sum of all the settlement in the sub-district. For more accurate describtion can be seen in figure 2 bellow. Kampong settlement surround more than half of the Manyar sub-district area. This was caused by kampong characteristic which grow organically along the increase in the number of the family moving to the urban area, the dwellings needs are also rising. The ecpantion caused by the settlement caused kampong settlement grown exponentially in the urban area.

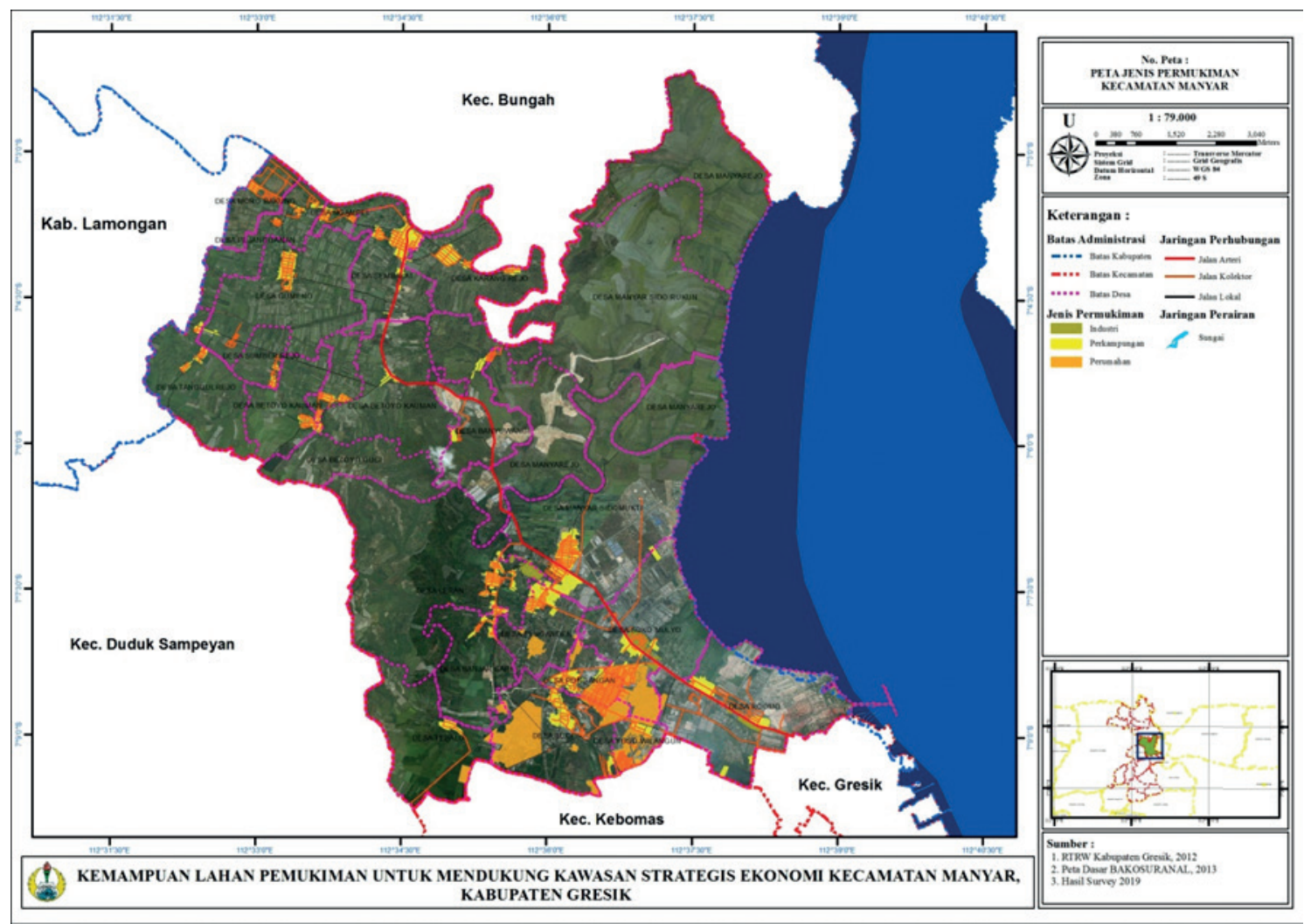

Figure 2

Map of Distribution and Types of Settlement in Manyar Sub-District. Resources : Rencana Tata Ruang Kabupaten Gresik 2012 (BAPPEDA, 2011), Peta dasar Bakosuranal 2013, Hasil survey 2019 
Figure 2 shows that in Manyar Sub-District has 3 types of settlements spread across 23 villages. The highest types of settlements are kampong settlements indicated by yellow and residential settlements with orange and lowest are industrial settlements indicated by dark yellow shown on the map.

\section{Needs of Facilities and Supporting Infrastructure Availability Settlements in Manyar Sub-District}

Scalogram analysis is used to identify the number, distribution and condition of the facilities and infrastructure supporting settlements as well as the ranking order of the areas based on the type and number of settlement infrastructure units. (Muta'ali, 2015). The results of the scalogram analysis show that there are 20 types of facilities in Manyar sub-District. Manyarejo Village has the most complete facilities with 17 types of facilities from 20 types of facilities in Manyar sub-district. The total number of the 17 facilities is 37 facilities. This shows that in Manyar sub-district, the distribution of service functions is not evenly distributed in all sub-districts. The higher the value of the completeness of the facilities in an area, the higher the service capability of the area (Muta'ali, 2015). Manyarejo has the highest service capability, while Morobakung village, Manyar sidorukun village, Tabalo village, Banyuwangi village, sumberejo village, Ngampel village dan Pejanganan village had the lowest service capabilities. The results of this study indicate that the distribution of the population and facilities and infrastructure is not evenly distributed.

\section{Population Projection on Manyar Sub-District}

The projected population of the Manyar Sub-District area, with the assumptions for the projected population of Manyar Sub-District over the next 20 years, from 2019-2039 to an increase of $1 \%$ each year. The population that experienced the highest increase was in the Suci Village, which from the beginning in 2019 the population reached 17,979 inhabit- ant in 2039 to 21,938 or it could be said that the population increase reached $19 \%$. In addition Suci Village in Yosowilangon Village also experiencing an increase at 2019 from 13.359 inhabitants and at he year 2039 the amounts add up to 16.301 inhabitant or around $11 \%$ and for the village which has the lowest amount of uptrend is Morobakung villafe with 2019 population reaches the number of 1.636 inhabitant and at the yar 2039 becames 1.997 inhabitant or around 1\%. With those results, manyar sub-district according to Regulation of the Head of the Central Statistics Agency (2010) is categorized as the 1\% -2\% classification

\section{Facilities and Infrastructure in Manyar Sub-District}

Manyar sub-District has 3 types of settlements namely kampong settlements with $335.38 \mathrm{Ha}$ or $52 \%$ of the total area of Manyar sub-District, there are also $275.28 \mathrm{Ha}$ or $42 \%$ of the total residential settlement area and finally industrial settlement with $39.84 \mathrm{Ha}$ or $6 \%$ of the total settlement area located in Manyar sub-District. Besides having 3 types of settlements, Manyar sub-District also has 20 types of settlement facilities with a total of 644 units spread across 23 villages in Manyar sub-District. This is in accordance with the condition of population growth that occurred in Manyar sub-District which has an increase of $1 \%$ per year. Manyar sub-district, after projecting the level of facilities and infrastructure needs for the next 20 years, has a high level of additional needs as follows:

\section{Facilities}

Manyar Sub-District requires the addition of 6 types of residential public service facilities including the following aspects such as housing facilities, education facilities, health facilities, worship facilities, commercial service facilities, and green open spaces. The education facilities with the total of 48.415 units seen from the number of back log homes from the previous 1.093 units. Education facilities need addition comparatively 58 units of kindergarten, 9 units of junior high 
school, and 10 units of elementary and high school level. The type of health facility that requires the lowest level of number of additions is a puskesmas which for 20 consecutive years requires only 1 additional unit and the highest was Posyandu with the increase to 100 units. The worship facilities total addition was mushalla which consist of 300 units and churches, temples, vihara with 39 units. For the commercial and services facilities, it require an increase of department shops of 20 units. Green Open Spaces needs more neighborhood association (RT) Scale Park of 500 units and citizen associaton (RW) Scale Park of 50 units.

From the results of the above description in accordance with the condition of population growth in the Sub-District of Manyar which reaches 1\% each year, it can be said that from the population growth in the Sub-District of Manyar has a low level of need for supporting housing facilities that includes several types of facilities include; educational advice, health facilities, worship facilities, trade facilities and services as well as green open space facilities for the next 20 years. In accordance with Indonesian National Standard no. 03-1733 in 2014 with the area of Manyar Sub-District reaching 9,542 $\mathrm{Ha}$ and the developed land of $269.1 \mathrm{Ha}$, it is very possible to do additional settlement support facilities according to the needs required (Badan Standarisasi Nasional, 2004).

\section{Infrastructures}

Infrastructure needs in Manyar sub-district consist of 5 types namely electricity network, telecommunication network, drainage network, clean water network and waste network. As for the road network, the projection results for the next 20 years do not require additions. These results are in accordance with the Indonesian national standard no 03-1733 in 2019 with the area of Manyar sub-District reaching 9,542 $\mathrm{Ha}$ and the developed land reaching $269.1 \mathrm{Ha}$ so it is very possible to do the addition of housing support infrastructure according to the needs needed ie for the next 20 years .
The greater the rate of population growth, more demands are made to fulfil the necessities of life and the social facilities needed to support the surrounding existence. (As'ari, Ruli, \& Fadjarani, 2018)(Rumengan, Kindangen, \& Takumansang, 2019). It causes more demand for land avaibility which surely pushes for the increasing land function changes (Prihatin, 2015). Land conversion occurs naturally in accordance with the fulfilment of the level of population needs, but this becomes unnatural if it is not controlled and becomes a problem as a consequence for the conversion of functions that occur on agricultural land or other productive land. (Prihatin, 2015).

The phenomenon above shows a tendency towards convertion of pond lands. This kind event has been happening since the year of 2002 to 2007 which consist of 5.491,91 Ha in Manyar sub-district. Conceding that the aquaculture sectors removed or undergoes a change of function, Gresik regency will ecperience an ecological imbalance and disproportion between sectors. Conclusively, this research proves there's needs to control pond lands conversion to facilitate the demand of settlement facilities and infrastructures.

\section{CONCLUSION}

The results of the analysis in this study for the conclusions that can be drawn in accordance with the expected results are the types of settlements in the Sub-District of Manyar including 3 types namely; kampong settlements, industrial settlements, and residential settlements. The population growth rate of Manyar Sub-District reaches 1\% every year and based on the schalogram analysis Manyar Sub-District has 19 types of housing support facilities including; education (kindergarten, elementary, junior high, senior high school and university). Health facilities (RSM, RSB, Clinic, Puskesmas, Pustu, Doctor's Clinic, Poskesdes, Posyandu dan Pharmacy), worship (mosques and prayer rooms), trade and services (shops, minimarkets, and traditional markets). The results of the needs analysis in 2039 require the addition of facili- 
ties and infrastructure to support settlements including; housing, education facilities (kindergarten, elementary school, junior high and high school), health facilities (RSM, RSB, Clinic, Puskesmas, Pustu, Doctor's Practice, Poskesdes, Posyandu and Pharmacy), worship facilities (Mushola and Church), commerce and services (Minimarket, Shop and shop Traditional Market), and green open spaces (neighborhood association park and citizen association park).

The need for additional facilities in residential area is a projection of 20 years population growth in Manyar sub-district. Those growth in Manyar sub-district is strongly influenced by the large-scale industrial activities which opens up new job opportunities, thus encouraging urbanization. The economic strategic area itself appeared due to activities in the industry that spur the agglomeration in the form of the development of new businesses such as food stalls, rental boarding houses, public transportation and other service providers (Lestari, 2018). This will gradually change land use, livelihoods, community socio-culture and socio-economy. According to Lestari (2018) Industrial activities have a positive impact in the form of providing new jobs so as to reduce unemployment so as to improve community welfare. Negative impacts in the form of changes in land use, shift in livelihoods, which were originally agricultural, farmers became employees or industrial employees, social changes in the form of comfort and health problems due to air pollution generated by industrial activities, traffic jams, noise, disturbed peace of residents and feelings worry and uneasiness increases. All of which need to be reviewed regarding the impact of industrial activities in the economic strategic area. Based on the large level of residential facilities and infrastructure needs in the next 20 years in Manyar sub-district, it is necessary to have further research to anticipate the phenomenon of pond land conversion by maintaining land functions.

\section{ACKNOWLEDGMENT}

Acknowledgments and appreciation, the writer needs to convey acknowledgements and appreciation to the various parties who have provided assistance in the form of guidance, direction, advice, support and facilities from the beginning to the end of the preparation of the research including the Gresik Regency government that has allowed the author to conduct research in the Gresik Regency precisely in the Manyar SubDistrict.

\section{BIBLIOGRAPHY}

Afriansyah, R., Wicaksono, A., \& Djakfar, L. (2012). Penentuan prioritas pengembangan jaringan jalan pendukung kawasan strategis di pulau sumbawa. Jurnal Rekayasa Sipil, 6(3), 214-225.

Anggreini, A., Wulandari, L. D., \& Ramdlani, S. (2018). Pola Ruang Permukiman Industri Mebel berdasarkan Aktivitas Industri (Studi Kasus : Industri Mebel Bukir Pasuruan). Repository Universitas Brawijaya, 1-8.

As'ari, Ruli, \& Fadjarani, S. (2018). Penataan Permukiman Kumuh Berbasis Lingkungan. Geografi, 15(1).

Badan Pusat Statistik. (2018). Kabupaten Gresik Dalam Angka Tahun 2018. Gresik.

Badan Standarisasi Nasional. (2004). Tata cara perencanaan lingkungan perumahan SNI 03 - 1733 - 2004 (2004). Jakarta.

BAPPEDA. (2011). Rencana Tata Ruang Dan Wilayah Kabupaten Gresik Tahun 2011 - 2031. Kabupaten Gresik.

Boeree, C. G. (2006). Personality Theories of Abraham Maslow (1908 - 1970). (C. G. Boeree, Ed.). Pennsylvania, Amerika Serikat: Shippensburg University. Retrieved from http://www.ship. edu/ cgboeree/perscontents.html

BPS. (2018). Kabupaten Gresik Dalam Angka 2018. Gresik.

Darmawan, S., \& Utami, T. B. (2018). Pola pemanfaatan ruang terbuka pada pemukiman kampung 
kota. Arsitektur, Bangunan Dan Lingkungan, 7(3), 127-136. Retrieved from https://media.neliti.com/ media/publications/265313-polapemanfaatan-ruang-terbuka-padapemu-21452603.pdf

Lestari, S. (2018). Dampak industri mie instan terhadap kondisi sosial dan ekonomi masyarakat desa sukomulyo kecamatan manyar kabupaten gresik. (Swara Bhumi, 1-7).

Mirah, E. M., Mononimbar, \& Tilaar, S. (2017). Perubahan Pemanfaatan Lahan di Kawasan Strategis Tumbuh Cepat Kapitu - Teep Kabupaten Minahasa Selatan. Spasial : Perencanaan Wilayah Dan Kota, 4(1), 147-173.

Muta'ali, L. (2015). Teknik Analisis Regional Untuk Perencanaan Wilayah, Tata Ruang dan Lingkungan. (I. A. Fadhil, Ed.) (Pertama). Yogyakarta: Badan Penerbit Fakultas Geografi Universitas Gadjah Mada.

Peraturan Kepala Badan Pusat Statistik Nomor 37 Tahun 2010. (2010). Tentang Klasifikasi Perkotaan dan Perdesaan di Indonesia.

Peraturan Pemerintah Republik Indonesia No. 26 Tahun 2008. (2008). Tentang Rencana Tata Ruang Wilayah Nasional. Jakarta.

Prihatin, R. B. (2015). Alih Fungsi Lahan di Perkotaan (Studi Kasus di Kota Bandung dan Yogyakarta). Jurnal Aspirasi, Vol. 6(No. 2), 105-118.
Putra, M., Giyarsih, S. R., \& Kurniawan, A. (2017). Sektor Unggulan dan Interaksi Antarwilayah pada Kawasan Strategis Nasional Perkotaan MEBIDANGRO. Jurnal Wilayah Dan Lingkungan, 5(3), 181. https://doi. org/10.14710/jwl.5.3.181-187

Rachmawati, S. D., \& Widyastuty, A. A. S. A. (2015). Status Kepemilikan Lahan Pendukung Pertumbuhan Permukiman Kumuh di Kawasan Rel. Waktu, 13(02), 54-62.

Rosa, Y. (2013). Rumusan Metode Backlog Rumah. Permukiman, 4(2), 58-68.

Rotinsulu, F. A., Franklin, P. J. ., \& Sembel, A. S. (2017). Analisis Ketersediaan Dan Kebutuhan Sarana Permukiman Di Kecamatan Kalawat. Spasial, 4(3), 4251. Retrieved from https://ejournal. unsrat.ac.id/index.php/spasial/ article/view/17299

Rumengan, M. R. C., Kindangen, J. I., \& Takumansang, E. D. (2019). Analisis Ketersediaan dan Kebutuhan Fasilitas Sosial di Kota Kotamobagu. SPasial, 6(2), 375-387.

Undang-undang Republik Indonesia Nomor 1 Tahun 2011. (2011). Tentang Perumahan dan Kawasan Permukiman. Jakarta.

Undang-undang Republik Indonesia Nomor 26 tahun 2007. (2007). Tentang Penataan Ruang. Jakarta.

Undang-undang Republik Indonesia Nomor 1 Tahun 2011. (2011). Tentang Perumahan dan Kawasan Permukiman. Indonesia. 